Review

\title{
Antioxidant Role of Kaempferol in the Management of Hepato- cellular Carcinoma
}

Nidhi Sharma ${ }^{1}$, Subhrajit Biswas ${ }^{2}$, Noura Al-Dayan ${ }^{3}$ and Maryam Sarwat ${ }^{1, *}$

1 Amity Institute of Pharmacy, Amity University, Noida-201313, Uttar Pradesh, India; nidhi13995@gmail.com

2 Amity Institute of Molecular Medicine \& Stem Cell Research, Amity University, Noida-201313, Uttar Pradesh, India; sbiswas2@amity.edu

3 Medical Laboratory Department, Applied Medical Science, Prince Sattam bin Abdul Aziz University, Saudi Arabia

* Correspondence: msarwat@amity.edu

\begin{abstract}
Reactive oxygen species (ROS) are noxious to cells because their increased level interacts with body's defense mechanism. These species also cause mutation and uncontrolled cell division resulting in oxidative stress. This stress is a well-recognized biological factor that has a prominent role in the progression of hepatocellular carcinoma (HCC). HCC is a critical global health problem and the third leading cause of cancer-related mortality globally. Recent studies show that the application of natural anti-oxidants from herbal sources significantly reduces oxidative stress. Kaempferol is a naturally occurring, aglycone dietary flavonoid that is present in various plants such as Crocus sativus, Coccinia grandis, Euphorbia pekinensis, varieties of aloe vera etc. It is capable of interacting with pleiotropic proteins present inside the human body. The breakthrough efforts are in progress to develop kaempferol as a potential candidate to manage HCC with no adverse effects. Activation of the ER stress-CCAAT/enhancer-binding protein homologous protein (CHOP) signaling pathway may be one of the molecular mechanisms of KP-induced hepatocellular apoptosis. Some researchers have demonstrated the action of KP via activation of caspase 3 and impairment of MAPK pathway. This review emphasizes the molecular mechanism of kaempferol involved in treating HCC targeting oxidative stress.
\end{abstract}

Keywords: free radicals; oxidative stress; hepatocellular carcinoma; anti-oxidants; kaempferol

\section{Introduction}

Kaempferol is a yellow-colored dietary flavonoid, present in numerous fruits and vegetables including broccoli, apples, strawberries, tea, saffron, aloe, and beans [1,2]. It is a tetrahydroxyflavone that has hydroxy groups located at positions 3, 5, 7, and 40 [3]. Kaempferol and its glycosylated derivatives are found to possess cardioprotective, neuroprotective, anti-inflammatory, antidiabetic, antioxidant, antimicrobial, and antitumor activities as shown in figure 1 [4]. Emerging evidence has demonstrated the antioxidant potential of kaempferol in liver injuries especially HCC. Kaempferol augments the antioxidant potential of normal cells via modulating heme oxygenase (HO)-1 expression and mitogen-activated protein kinase (MAPK) pathways [5]. The HO-1 is a redox-sensitive inducible enzyme whose overexpression enhances cell resistance to oxidative injury. 


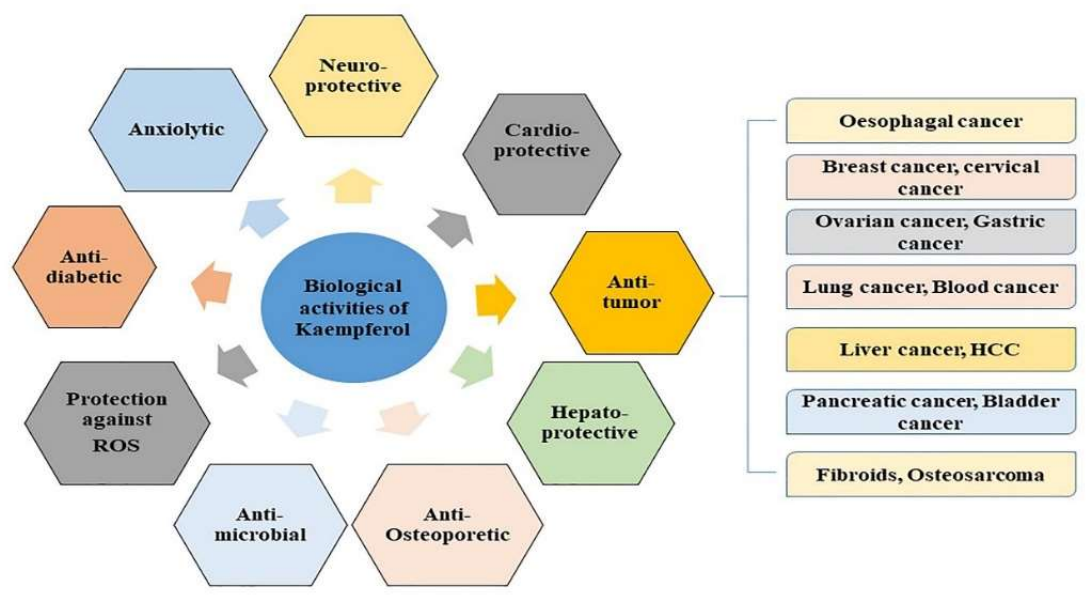

Figure 1. Pharmacological activities of kaempferol.

Reactive oxygen species (ROS) are the active metabolites of healthy cells which include free radicals, such as superoxide $(\mathrm{O} 2 \cdot-)$ and hydroxyl radical $(\mathrm{OH} \cdot)$, as well as nonradical species, such as hydrogen peroxide (H2O2) [6]. The sequential reduction of oxygen leads to the genesis of these species. The physiological concentration of ROS is essential in carrying out vital cellular processes including proliferation, apoptosis, cell cycle arrest, and cell senescence whereas high ROS flux damages cell macromolecules including proteins, lipids, and nucleic acids (DNA and RNA)[7]. Therefore, the smooth conduction of all metabolic functions requires a balanced redox state. Oxidative stress occurs due to the overproduction of ROS generated by endogenous (e.g., mitochondria, peroxisomes, and oxygen-handling enzymes) and exogenous sources (e.g., UV, heavy metals, and micronutrients) or by inefficient/exhausted antioxidants [6]. ROS-mediated oxidative stress may lead to the development of various chronic diseases such as infectious diseases, cardiovascular diseases, neurodegenerative diseases, allergy, and carcinogenesis.

Hepatocellular carcinoma (HCC) is the most lethal and third leading cause of cancer-related mortality worldwide [8]. Risk factors such as hepatitis B virus (HBV), hepatitis C virus $(\mathrm{HCV})$, aflatoxin-contaminated food, cirrhosis, diabetes mellitus, obesity, alcohol abuse, smoking, and non-alcoholic fatty liver diseases (NAFLD) are involved directly and indirectly in the pathogenesis of HCC [9]. Various curative therapies such as surgical resection, liver transplantation, radiofrequency ablation, and systemic targeted therapy with sorafenib are available but are associated with high chances of recurrence and resistance [10]. HCC is a multi-stage process that involves various complex pathways in its pathogenesis including RAF/ERK/MAPK, PI3K/Akt/Mtor, Ras \& JAK-STAT, Wnt- and RB1-dependent signaling cascade. Dysregulation of ROS producing and ROS scavenging enzymes contributes to the development of HCC leading to poor patient survival. This review summarizes the mechanism of the antioxidant potential of kaempferol in treating HCC.

\section{Oxidative stress (OS) in hepatocarcinogenesis.}

The mechanism that contributes to hepatocarcinogenesis involves several operations such as tumor suppressor function attenuation, oncogene activation, and oxidative stress. 
Oxidative stress could be promoted by any dangerous or inflammatory signal which damages hepatocytes, promotes pathological polyploidization, triggers inflammation, and contributes to the development of insulin resistance [11]. Additionally, it is also involved in migration, invasion, and metastasis of HCC for different etiologies. Acute liver injury \& chronic inflammation generates ROS by the activation of neutrophils and Kupfer cells. More the $80-90 \%$ of HCC are associated with chronic hepatic inflammation, Non- alcoholic steatohepatitis (NASH), and hepatitis B virus (HBV), and hepatitis $\mathrm{C}$ virus (HCV).

\subsection{HBV \& HCV related HCC and oxidative stress}

Chronic HBV and HCV infection play an important role in the development of cirrhosis, which is found in $80 \%$ to $90 \%$ of patients with HCC [12]. These unrelated viruses belong to two different viral families, exhibit strong hepatotropism but their molecular mechanism in HCC is not known clearly. HBV is a DNA virus belonging to the hepadnaviridae family [13], consisting of a relaxed circular DNA genome that is enclosed by the enveloping proteins [14] whereas HCV is a member of the flaviviridae family of enveloped, positive-strand RNA viruses [15]. Some researchers have found the viral encoded proteins are accountable for altering the cellular phenotype and the host gene expression which is the hallmark of cancer [16]. HBV and HCV-related fibrosis and chronic inflammation of the liver are usually induced by OS, which eventually contributes to the development of HCC. $\mathrm{HBV}$ infection leads to the activation of macrophages or Kupffer cells to produce proinflammatory cytokines, including IL-1 $\beta$, IL-6, and TNF- $\alpha$ [17]. Irregular cytokines generation and ROS production have an influential role in hepatocarcinogenesis.

The HBV genome is associated with various gene products, such as DNA polymerase (Pol), the capsid protein (core), envelope proteins $\mathrm{L}, \mathrm{M}$, and $\mathrm{S}$, and the multifunctional protein HBx [18]. Several studies display the carcinogenic potential of HBx protein which leads to the production of ROS in mitochondria and augments oxidative stress [19]. Transactivated HBx protein helps in stimulating virus replication and expression and protects the virus-infected cells from damage [20].

The HBx protein in the cytoplasm gets accumulated, and the c-terminal region from HBx's truncation is the producing region of ROS. This process takes place in $46 \%$ of the HCC tissues and not in healthy tissues. This is the key process in the progression of hepatocarcinogenesis that HBV genes incorporate into the host genome. TERT, MLL4, and CCNE1 are the several cancer-related genes that may also be integrated by HBV [21]. HBx, the most common gene that is integrated into the human genome.

Alteration in the Samples from HBV patients shows that mutation at genetic level is associated with the initiation and development of liver cancer, highlighting the role of HBx in HCC development. Recent shreds of literature proves that the mutant genes and their products accumulate in the ER and promote carcinogenesis through ER stress and ROS production. This is how oxidative stress contributes to the process of HBV-related liver cancer development through HBx protein [22].

In HCV infection, liver antigen-presenting cells get activated and regulate the immune functions [23]. Upregulation of immunomodulatory molecules such as PD-L1 in Kuffer cells is the most prominent effect of HCV on inflammatory signaling pathways [24]. Continuous inflammation leads to the development of HCC as liver cells undergo the circulation between the time of apoptosis and regeneration. $\mathrm{HCV}$ antigens, specifically the core protein, contribute to the pathogenesis of chronic HCV and hepatocarcinogenesis via PKR, STAT3, and TNFR pathways [25]. OS is also related to infirmity, which is also one of the driving factors of liver cancer. 


\subsection{NASH related HCC and OS}

Non-alcoholic steatohepatitis (NASH) is the critical form of NAFLD (a hepatic metabolic syndrome with insulin resistance, altering the physiology of the liver). It is a chronic liver injury that is defined by the presence of steatosis with inflammation and progressive fibrosis, which ultimately leads to cirrhosis and HCC [26]. 20 years back, Day and James proposed that the pathogenesis of NASH is a two-hit theory [27]. The first hit in the progression of steatosis is correlated with the accumulation of triglycerides in the liver cells whereas the second hit includes the wide variety of cellular stress factors including oxidative stress, apoptosis, ER stress, gut-derived stimulation, and intestinal circumstances [28]. In the first hit, lipid accumulation in hepatocytes is due to the overconsumption of more carbohydrates or saturated fatty acids and less polyunsaturated fatty acids. Adiponectin, resistin, and tumor necrosis factor-alpha (TNF- $\alpha$ ) are the factors released by adipose tissues of the patients having NAFLD. These factors contribute to inflammation of the cell and insulin resistance which in turn, induces mitochondrial destruction and generation of ROS (a key factor of oxidative stress) [29].

The genetic investigation has demonstrated that a hepatic increase in triglyceride and free fatty acid levels can lead to advanced NASH. Genes encoding for patatin-like phospholipase domain containing 3 (PNPLA3) and transmembrane 6 superfamily member 2 (TM6SF2) have a strong connection with the severity of steatosis, NASH, and fibrosis or cirrhosis [30]. Patients carrying the PNPLA3 polymorphism are not only at a greater risk of steatohepatitis and fibrosis but also have more than the threefold increased risk of HCC [31].

Oxidative stress is a harmful key component that adds to the progression of NASH to HCC. ROS are the metabolic by-products in hepatocytes generated due to elevated mitochondrial fatty acid oxidation and inadequate mitochondrial respiratory chain activity. The ROS level tends to increase in NASH or NAFLD [32] and results in disruption of hepatic fatty acid homeostasis and accumulates non-metabolized fatty acids in the cytoplasm [33].

Table 1. Role of oxidative stress on HBV, HCV, and NASH related HCC

\begin{tabular}{|c|c|c|c|c|}
\hline S.No & Cause & $\begin{array}{c}\text { Factors } \\
\text { Activated }\end{array}$ & $\begin{array}{c}\text { Mechanism } \\
\text { Involved }\end{array}$ & $\begin{array}{c}\text { Impact on } \\
\text { oxidative } \\
\text { stress and } \\
\text { HCC }\end{array}$ \\
\hline \multirow[t]{2}{*}{1.} & $\begin{array}{c}\text { Hepatitis B Virus } \\
(\mathrm{HBV})\end{array}$ & $\begin{array}{c}\mathrm{HBx} \\
\text { protein }\end{array}$ & $\begin{array}{c}\uparrow \text { Oncogene } \\
\text { expression. } \\
\text { Activate } \\
\text { signaling } \\
\text { pathways, } \\
\text { Apoptosis }\end{array}$ & $\begin{array}{c}\uparrow \mathrm{ROS} \text { and } \\
\mathrm{HCC}\end{array}$ \\
\hline & & $\begin{array}{c}\text { Gene } \\
\text { mutation }\end{array}$ & Induce ER stress & \\
\hline 2. & $\begin{array}{c}\text { Hepatitis C Virus } \\
(\mathrm{HCV})\end{array}$ & $\begin{array}{c}\text { Core } \\
\text { Protein }\end{array}$ & $\begin{array}{l}\text { Activates } \\
\text { Signaling } \\
\text { Pathways }\end{array}$ & $\begin{array}{c}\uparrow \mathrm{ROS} \text { and } \\
\mathrm{HCC}\end{array}$ \\
\hline
\end{tabular}




\begin{tabular}{|c|c|c|c|c|}
\hline & & $\uparrow \mathrm{Fe} 2+$ & Fenton reaction & \\
\hline \multirow[t]{2}{*}{3.} & NASH & $\begin{array}{l}\text { Fatty } \\
\text { toxicity }\end{array}$ & $\uparrow \quad \mathrm{IL}-17$ & $\begin{array}{c}\uparrow \mathrm{ROS} \text { and } \\
\mathrm{HCC}\end{array}$ \\
\hline & & $\begin{array}{l}\text { Central } \\
\text { Obesity }\end{array}$ & $\begin{array}{l}\text { Reduces the } \\
\text { level of } \\
\text { adiponectin }\end{array}$ & \\
\hline
\end{tabular}

\section{Antioxidant potential of kaempferol in managing HCC}

Plant-derived natural products have shown excellent activity in defending the body from exogenous and endogenous stress factors. Flavonoids are the clusters of naturally occurring polyphenolic biological products that are present in vegetables \& fruits and are the essential components in the human diet [34]. The tremendous bioactive flavonoid, kaempferol, possesses a remarkable spectrum of pharmacological activities including antidepressant, anxiolytic, anti-inflammatory, antitumor, etc. [35]. Researchers have indicated the antioxidant potential of kaempferol in both in-vitro \& invivo models. Kaempferol comprises hydroxyl groups at C3, C5, and C4, an oxo group at C4, and a double bond at $\mathrm{C} 2-\mathrm{C} 3$ that might illustrate its antioxidant activity [36]. It works by scavenging the free radicals and other reactive oxygen species (ROS) as their generation transforms the normal cells into malignant ones. So, inhibition of these species alters tumor cell phenotype. Zang et al., 2017 demonstrated kaempferol pre-treatment in CCl4 challenged ddY mice showed normalized activities of liver ALT, AST, hepatic glutathione, superoxide dismutase, catalase, and glutathione peroxidase [37]. Furthermore, the liver thiobarbituric acid reactive substances levels were found to be improved by pretreatment with $\mathrm{KG}$, indicating that $\mathrm{KG}$ is available to alleviate liver injury, which might be due to its antioxidant properties. The role of kaempferol in managing severe liver injuries are summarized in table 2 .

Table 2. In-vitro and in-vivo studies of kaempferol in liver diseases.

\begin{tabular}{|c|c|c|c|c|}
\hline S.No & $\begin{array}{l}\text { Diseases } \\
\text { type }\end{array}$ & Mechanism of action & $\begin{array}{c}\text { In-vitro/In-vivo } \\
\text { model }\end{array}$ & References \\
\hline 1. & $\begin{array}{l}\text { Acute liver } \\
\text { failure }\end{array}$ & $\begin{array}{l}\text { Regulation of ER stress- } \\
\text { Grp78-CHOP pathway }\end{array}$ & $\begin{array}{l}\text { Murine ALF model } \\
\text { induced by D- } \\
\text { galactosamine / } \\
\text { lipopolysaccharide } \\
\text { mice }\end{array}$ & {$[61]$} \\
\hline 2. & $\mathrm{HCC}$ & $\begin{array}{l}\uparrow \text { Protein level of Atg5, } \\
\text { Atg7, Beclin1, and } \\
\text { Overexpression of } \\
\text { CHOP induces } \\
\text { autophagy. }\end{array}$ & HepG2 \& Huh 7 & {$[60]$} \\
\hline 3. & $\mathrm{HCC}$ & $\begin{array}{l}\text { Apoptosis, and } \\
\text { Upregulation of CHOP } \\
\text { gene expression. }\end{array}$ & HepG2 & [59] \\
\hline
\end{tabular}




\begin{tabular}{|c|c|c|c|c|}
\hline 4. & $\mathrm{HCC}$ & $\begin{array}{lr}\text { HIF-1a } & \text { activity } \\
\text { inactivation } & \text { by } \\
\text { cytoplasmic } & \\
\text { mislocalization } & \text { and } \\
\text { MAPK } & \text { pathway } \\
\text { inhibition. } & \end{array}$ & Huh 7 & [62] \\
\hline 5. & $\mathrm{HCC}$ & $\begin{array}{l}\mathrm{H}_{2} \mathrm{O}_{2} \text { mediated lipid } \\
\text { peroxidation leading to } \\
\text { cell death \& DNA } \\
\text { damage, } \uparrow \text { the activity of } \\
\text { caspases- }-2,-3 / 7,-9 \text {, and } \\
-8 / 10 \text {, and apoptosis. }\end{array}$ & H4IIE & {$[63]$} \\
\hline 6. & Liver injury & $\begin{array}{l}\text { Suppressed oxidative } \\
\text { stress, /the normalized } \\
\text { level of serum ALT, } \\
\text { AST activities, hepatic } \\
\text { glutathione, superoxide } \\
\text { dismutase, catalase, and } \\
\text { glutathione peroxidase. }\end{array}$ & ddY mouse model & [37] \\
\hline 7. & $\begin{array}{l}\text { Alcoholic } \\
\text { liver injury }\end{array}$ & $\begin{array}{l}\text { Increased antioxidant } \\
\text { defense activity, } \\
\text { Decreased oxidative } \\
\text { stress, and lipid } \\
\text { peroxidation. }\end{array}$ & $\begin{array}{c}\text { HepG2/ ALI mice } \\
\text { model }\end{array}$ & [64] \\
\hline 8. & Liver fibrosis & $\begin{array}{l}\text { Down-regulation of } \\
\text { hyaluronic acid, ALT, } \\
\text { AST, Smad2/3. } \\
\text { Inhibit collagen } \\
\text { synthesis and activation } \\
\text { of HSCs cells. } \\
\text { Suppression of activin } \\
\text { receptor-like kinase } 5 .\end{array}$ & $\begin{array}{l}\text { HSCs/Ccl4 induced } \\
\text { mouse model }\end{array}$ & [65] \\
\hline 9. & Liver cancer & $\begin{array}{lr}\text { Apoptosis, } & \text { reduced } \\
\text { expression of } & \text { miR-21, } \\
\text { Upregulation of } & \text { PTEN } \\
\text { expression } & \& \\
\text { PI3K/AKT/mTOR } \\
\text { signaling pathways } \\
\text { inactivation. }\end{array}$ & HepG2 & [66] \\
\hline
\end{tabular}




\begin{tabular}{|c|c|c|c|c|}
\hline 10. & $\mathrm{HCC}$ & $\begin{array}{l}\uparrow \text { The hypolipidemic } \\
\text { effect through LDL-c } \\
\text { uptake. }\end{array}$ & HepG2 & {$[67]$} \\
\hline 11. & $\begin{array}{l}\text { Acrylamide } \\
\text { hepatic } \\
\text { intoxication }\end{array}$ & $\begin{array}{l}\text { Reduced TBAR and } \\
\text { GSH level }\end{array}$ & $\begin{array}{l}\text { Wistar female } \\
\text { albino rats }\end{array}$ & [68] \\
\hline 12. & $\begin{array}{l}\text { Hepatotoxicit } \\
\mathrm{y}\end{array}$ & $\begin{array}{l}\text { Decreased level of ALT, } \\
\text { AST. Induce } \\
\text { hepatocellular damage, } \uparrow \\
\text { expression of } \\
\text { antioxidant enzymes, } \\
\text { and apoptosis. Reduces } \\
\text { NLRP3 expression \& } \\
\text { pro-inflammatory } \\
\text { factors. Inhibition of } \\
\text { HMGBI/TLR4/NF-KB } \\
\text { signaling pathway. }\end{array}$ & $\begin{array}{l}\text { Male C57BL/6 } \\
\text { mice }\end{array}$ & [69] \\
\hline 13. & $\begin{array}{l}\text { Alcoholic } \\
\text { liver injury } \\
(\mathrm{AALI})\end{array}$ & $\begin{array}{l}\uparrow \text { Expression of butyrate } \\
\text { receptors, transporters, } \\
\text { and } \mathrm{TJ} \text { proteins in the } \\
\text { intestinal mucosa. }\end{array}$ & Mice & [70] \\
\hline 14. & Liver injury & $\begin{array}{l}\downarrow \text { TBARS \& TNF- } \alpha \text { level } \\
\text { in CCL4 treated mice. }\end{array}$ & Male ddY mice & {$[37]$} \\
\hline 15. & $\begin{array}{l}\text { Nonalcoholic } \\
\text { steatohepatiti } \\
\text { s (NASH) }\end{array}$ & $\begin{array}{l}\downarrow \text { level of ALT, LDL, } \\
\text { triglycerides, total } \\
\text { cholesterol, lipid } \\
\text { droplets \& inflammatory } \\
\text { cells infiltration in the } \\
\text { liver, Upregulation of } \\
\text { DEGs, Regulation of } \\
\text { fatty acid degradation, } \\
\text { expression of } \\
\text { cytochrome P450, } \downarrow \\
\text { level of urinary proteins } \\
\text { family (Mup17, Mup7, } \\
\text { and Mup16). }\end{array}$ & $\begin{array}{l}\text { Male C57BL/6 } \\
\text { mice }\end{array}$ & [71] \\
\hline
\end{tabular}




\begin{tabular}{|c|c|c|c|c|}
\hline 16. & $\begin{array}{l}\text { Human } \\
\text { hepatic } \\
\text { cancer }\end{array}$ & $\begin{array}{l}\uparrow \text { protein levels of p- } \\
\text { AMPK, LC3-II, Atg 5, } \\
\text { Atg 7, Atg } 12 \text { and Beclin } \\
1, \downarrow \text { level of CDK1, } \\
\text { cyclin B, p-AKT, and p- } \\
\text { Mtor. Downregulation of } \\
\text { CDK1/Cyclin } \\
\text { pathways, } \\
\text { autophagy. }\end{array}$ & SK-HEP-1 & [72] \\
\hline 17. & Liver injury & $\begin{array}{l}\text { Inhibition of OATP1B1 } \\
\text { transporter, maintaining } \\
\text { a level of AST, ALT }\end{array}$ & HEK-293 cells & [73] \\
\hline 18. & $\mathrm{HCC}$ & $\begin{array}{l}\uparrow \text { phosphorylation of } \\
\text { JAK1, Tyk2, and } \\
\text { STAT1/2, } \\
\text { phosphorylation } \quad \downarrow \\
\text { STAT3, of } \\
\text { endogenous } \quad \text { IFN- } \alpha- \\
\text { regulated genes } \\
\text { expression, } \downarrow \text { expression } \\
\text { of SOCS3, } \uparrow \text { the anti- } \\
\text { proliferative effect of } \\
\text { IFN- } \alpha, \text { activation of the } \\
\text { JAK/STAT signaling } \\
\text { pathway }\end{array}$ & HepG2 cells & [74] \\
\hline 19. & Liver cancer & $\begin{array}{l}\uparrow \text { PIG3 level at mRNA } \\
\text { and protein level, } \uparrow \text { ROS } \\
\text { production, Cytochrome } \\
\mathrm{C} \quad \text { release, } \\
\text { mitochondrial } \\
\text { membrane potential, } \\
\text { upregulation of Bax/Bcl- } \\
2 \text {, activation of caspases- } \\
9 \quad \text { and }-3, \quad \text { and } \\
\text { maintaining the } \\
\text { prooxidant activity. }\end{array}$ & HepG2 cells & [75] \\
\hline 20. & Liver injury & $\begin{array}{l}\text { Inhibition of lipid } \\
\text { peroxidation caused by } \\
\text { CCL4 reactive free } \\
\text { radicals. }\end{array}$ & $\begin{array}{c}\text { Male Swiss albino } \\
\text { rats }\end{array}$ & [76] \\
\hline
\end{tabular}




\begin{tabular}{|c|c|c|c|c|}
\hline 21. & NAFLD & $\begin{array}{l}\downarrow \quad \text { hepatic lipid } \\
\text { accumulation, promote } \beta \\
\text { oxidation in } \\
\text { mitochondria \& up- } \\
\text { regulation of the } \\
\text { expression of CPT1A }\end{array}$ & HepG2 cells & [77] \\
\hline 22. & Liver injury & $\begin{array}{l}\text { Reduces AA+Fe- } \\
\text { induced ROS production } \\
\text { and reversed glutathione } \\
\text { depletion, } \downarrow \text { cell death. }\end{array}$ & $\begin{array}{c}\text { HepG2 cells \& } \\
\text { mice. }\end{array}$ & [78] \\
\hline 23. & Liver fibrosis & $\begin{array}{l}\downarrow \text { Protein levels of } \\
\text { cleaved caspase-3, } \uparrow \text { p- } \\
\text { ERK1/2, PI3K, and Bcl- } \\
\text { XL protein expression in } \\
\text { TNF- } \alpha \text {-stimulated L02 } \\
\text { cells. The suppressed } \\
\text { proliferation of LX2 } \\
\text { cells and up-regulation } \\
\text { of Bax and cleaved } \\
\text { caspase- } 8 \text {. }\end{array}$ & L02, LX2 \& Rats & [79] \\
\hline
\end{tabular}

\subsection{Pathways targeted by kaempferol in relieving oxidative stress}

\subsubsection{Peroxisome proliferator-activated receptor (PPAR)}

PPAR belongs to the nuclear receptor superfamily [38]. Among the various PPAR receptors identified, PPAR $\alpha$ \& PAR $\gamma$ exert an important role in the regulation of lipids and glucose metabolism [39]. The subtypes of PPAR receptors have been featured for their involvement in the pathogenesis of HCC. Due to increased consumption of nutrients, HCC cells experience oxygen and nutrient deficiency leading to a stressful metabolic environment [40]. Especially in the liver, PPAR $\alpha$ acts as a master regulator of liver metabolism. PPAR $\alpha$-regulated processes are thought to be involved in all liver diseases. A great deal of study has demonstrated the low expression of PPAR $\alpha$ receptors in HCC cells. Therefore stimulation of PPAR $\alpha$ is expected to treat HCC. Kaempferol, a polyphenolic compound shows the protective effect by elevating the expression of the PPAR $\alpha$ gene and/or protein [41]. 


\subsubsection{Nuclear factor erythroid 2 [NF-E2]-related factor 2 (Nrf2) related oxidative stress}

Nrf2, a cytosolic transcription factor, is the supreme regulator of cellular defense through the mediation of the antioxidant system [42]. In the normal liver cells, Nrf2 offers protective effects against oxidative stress whereas in the tumor cells it causes deleterious effects encouraging the proliferation and survival of cancerous cells [43]. Under physiological conditions, Nrf2 resides in association with Kelch-like ECH-associated protein 1 (KEAP1) is known to orchestrate the NRF2-dependent oxidative stress response to maintain liver homeostasis. Upon continuous stress exposure, Keap 1 degrades in the cytoplasm. Further Nrf2 is phosphorylated and translocates to the nucleus, forms a heterodimer with transcription factor Maf, and binds to the antioxidant response element (ARE) sequence to activate the encoding endogenous antioxidants, phase II detoxifying enzymes \& transporters [44]. For this reason, Nrf2 may become the potential target in managing severe cancers including HCC. Emerging reports have indicated the promising role of kaempferol in combatting cancer by regulating the Nrf2 transcriptional pathway and thus reducing cell redox homeostasis [36]. Figure 2 is displaying the antioxidant mechanism of kaempferol in hepatocellular carcinoma.

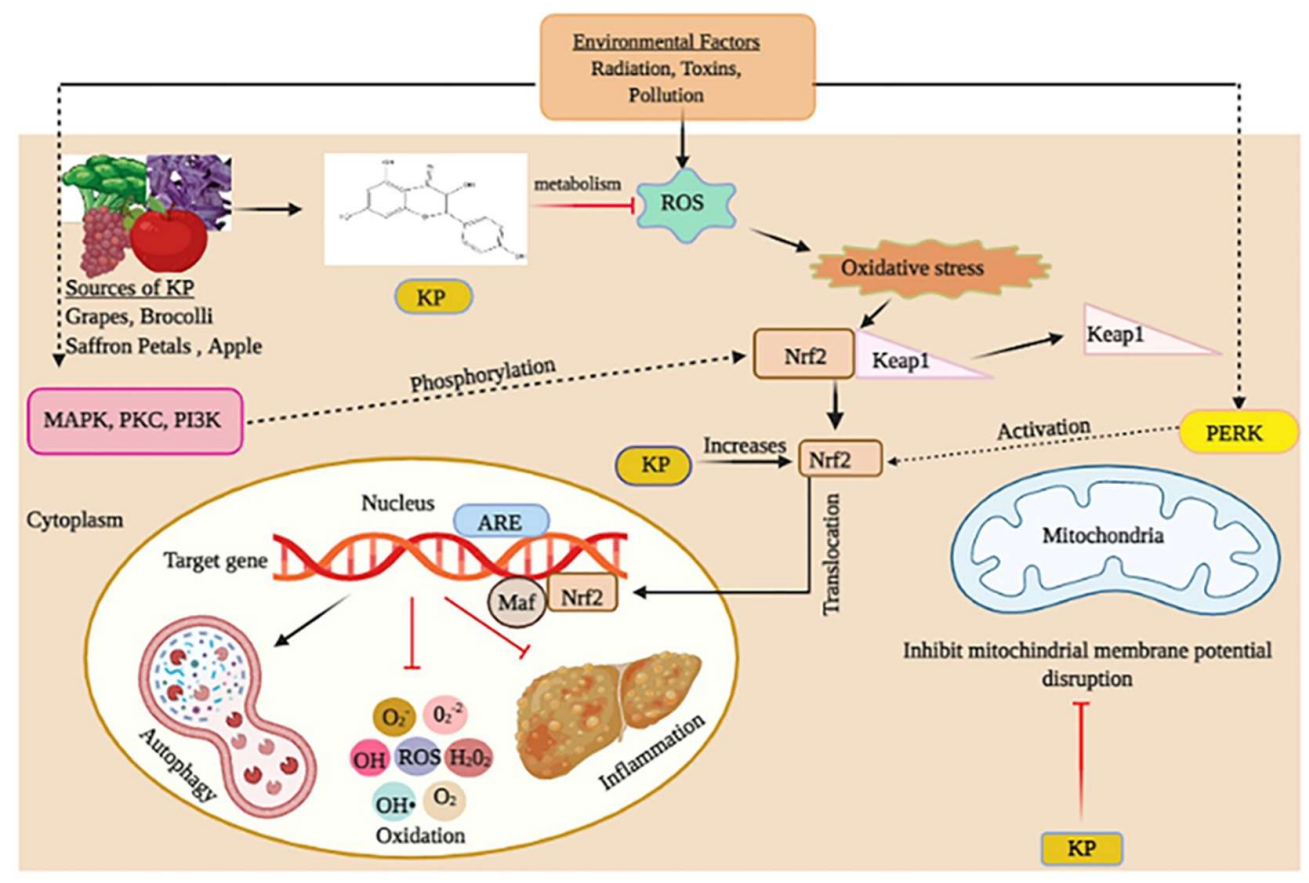

Figure 2. Antioxidant mechanism of KP via Nrf2-Keap1 pathway. KP present in numerous fruits and vegetables inhibits the metabolism of ROS by acting on the Nrf2-Keap1 complex. The level of Nrf2 is augmented by KP after its disassociation from the complex. Nrf2 further translocates to the nucleus and thereby maintaining the expression of targeted genes. KP also plays a vital role in suppressing the mitochondrial membrane potential disruption in regulating the expression of cancerrelated genes. KP- Kaempferol, Nrf2- Nuclear factor erythroid 2 related factors 2; Keap1- Kelch-like ECH-associated protein 1.

\section{Role of Kaempferol in ER Stress \& oxidative stress-induced apoptosis}

The endoplasmic reticulum (ER) is a cellular organelle involved in numerous functions such as protein folding, synthesis, and secretion [45]. Nutrient distress, $\mathrm{pH}$ imbalance, and, hypoxia are the stimuli that create perturbation in ER homeostasis leading to a condition called ER Stress [46]. This further leads to the activation of a self-protective mechanism selectively called, an unfolded response (UPR). It works by reducing the protein synthesis and enhancing the expression of ER molecular chaperones glucose-regulated protein 78 (GRP78) and GRP94 to facilitate the correct folding of proteins. UPR is the complex cellular response that is associated with the different membrane biosensors; protein kinase RNA (PKR)-like ER kinase (PERK), inositol requiring enzyme $1 \alpha$ (IRE1 $\alpha$ ), and activating transcription factor 6 (ATF6) [38]. 


\subsection{Endoplasmic reticulum stress signaling pathways}

\subsubsection{IRE1 $\alpha-X B P 1$ pathway}

IRE1 is the transmembrane type-I protein that possesses both kinase and endoribonuclease (RNAse) activities and helps in modulating ER stress. IRE1 exists in two isoforms, IRE1 $\alpha$ and IRE1 $\beta$. The IRE1 $\alpha$ is expressed extensively and its knockout in mice exhibits embryonic lethality whereas IRE1 $\beta$ expression is confined to the intestinal epithelium and gastrointestinal tract. Also, its knockout in mice is viable due to which IRE1 $\alpha$ is considered a positive regulator for mammalian cell survival [47]. Upon ER stress condition, IRE1 $\alpha$ disassociates from GRP78/Bip [48], undergoes dimerization, Author Contributions: For research articles with several authors, a short paragraph specifying their individual contributions must be provided. The following statements should be used "Conceptualization, X.X. and Y.Y.; methodology, X.X.; software, X.X.; validation, X.X., Y.Y. and Z.Z.; formal analysis, X.X.; investigation, $X . X . ;$ resources, $X . X . ;$ data curation, $X . X . ;$ writing-original draft preparation, $X . X . ;$ writing - review and editing, X.X.; visualization, $X . X . ;$ supervision, $X . X . ;$ project administration, X.X.; funding acquisition, Y.Y. All authors have read and agreed to the published version of the manuscript." Please turn to the CRediT taxonomy for the term explanation. Authorship must be limited to those who have contributed substantially to the work reported.

Funding: Please add: "This research received no external funding" or "This research was funded by NAME OF FUNDER, grant number XXX" and "The APC was funded by XXX". Check carefully that the details given are accurate and use the standard spelling of funding agency names at https://search.crossref.org/funding. Any errors may affect your future funding. and autophosphorylation [49]. X-box binding protein 1 (XBP-1) mRNA is the first substrate described for IRE1 $\alpha$ endonuclease activity [50] which stimulates the non-conventional splicing of Xbp- 1 mRNA to produce its active form that is spliced XBP1 [51]. This activated form of XBP1 encourages the expression of ER quality-control genes, thus enhancing the protein folding capacity of the ER. Spliced XBP1 modulates the expression of genes involved in protein folding, secretion, redox homeostasis, oxidative stress response, and ER-associated degradation (ERAD) [38, 52]. IRE1 $\alpha$-XBP1 signaling has been reported to possess a prominent role in human cancer including hepatocellular carcinoma. Additionally, cancer cells which are deficient of XBP1 protein and are more sensitive to ER stress and hypoxic condition.

\subsubsection{PERK-eIF2 $\alpha$-ATF4 Pathway}

The enzyme Protein Kinase R (PKR)-like Endoplasmic Reticulum Kinase (PERK) is an ER transmembrane protein that is associated with BiP/GRP78 in its inactive form. It gets activated by liberating Bip/GRP78 and undergoes oligomerization and autophosphorylation in response to UPR activation [53]. Active PERK plays an important role in suppressing global protein synthesis by attenuating the translation of mRNA and inhibiting the entry of new proteins into the ER lumen. This process is regulated by phosphorylation-mediated inactivation of the eukaryotic translation initiation factor 2 (eIF $2 \alpha$ ). Phosphorylation of eIF $2 \alpha$ at ser51 residue inhibits protein translation by reducing the cyclin D1 pool and cell cycle arrest at the G1 phase which ultimately diminishes protein burden and helps the cells to overcome the stressful conditions [54]. The activated PERK- eIF2 $\alpha$ promotes the translation of ATF4 which encourages cell survival by regulating protein biosynthesis and its transport. Cells lacking PERK are reported to be supersensitive to ER stress conditions. Based on this, the inhibition of the PERK- eIF2 $\alpha$-ATF4 signaling pathway could be a promising target for cancer management.

\subsubsection{ATF6 Pathway}

ATF6 is the cytoprotective factor and ER stress modulator that participates actively in the UPR signaling pathway [55]. It is a type II transmembrane protein that belongs to the leucine zipper family of transcription factors [56]. Under the chronic ER stress, an isoform ATF6 $\alpha$ disassociates from the GRP78 proteins and translocate to the Golgi apparatus where it undergoes proteolysis by the resident Site 1 (S1P) and Site 2 (S2P) proteases. This releases a cytosolic fragment that migrates to the nucleus and regulates gene transcription [54]. To maintain ER hemostasis, cleaved ATF6 $\alpha$ plays a prominent role in the regulation of genes involved in protein synthesis and ER-associated degradation (ERAD) [57]. In this way, ATF6 $\alpha$ is important for liver development and also for cell survival. 
Uncontrolled and prolonged ER stress leads to cellular damage and eventually induces apoptosis by activating the mitochondrial intrinsic apoptotic pathway [58]. Proteins in the caspase family are the primary drivers of apoptosis. Human caspase- 4 is uniquely located in the ER membrane, where it is specifically activated by ER stress. Similar to caspase- 12 in mice, caspase- 4 activates caspase-9, in addition to other molecules such as caspase-3, eventually resulting in cell apoptosis. Guo et al., 2016 has demonstrated kaempferol induces apoptosis in HepG2 cell line via ER stress- CHOP signaling pathway induced apoptotic by increasing the protein expression levels of glucose-regulated protein 78, glucose-regulated protein 94, protein kinase R like ER kinase, inositol requiring enzyme $1 \alpha$, partial activating transcription factor 6 cleavage, caspase 4, C/EBP homologous protein (CHOP) and cleaved caspase 3 [59]. Kaempferol induces autophagy in HepG2 and Huh7 cell lines in a concentration and dose-dependent manner via ER Stress and CHOP autophagy signaling pathway [60]. Kaempferol impedes hepatocyte apoptosis to protect mice from liver failure by regulating the ER stress-Grp78-CHOP signaling pathway [61]. Niering et al., 2005 demonstrated the protective effect of kaempferol in H4IIE rat hepatoma cells over a broad concentration range by inducing oxidative stress and apoptosis.

\section{Conclusion}

Oxidative stress is a toxic response in all liver cancer especially HCC. Managing the dynamic balance of ROS is an effective approach to maintain good health. A significant improvement in the condition of HCC patients has been linked to the intake of fruits and vegetables rich in various bioactive molecules such as kaempferol. Scientists have revealed the antioxidant potential of kaempferol in managing HCC both in in-vitro and in-vivo conditions. Existing literature reflects that kaempferol is not just a potent promoter of apoptosis but it also modifies the cellular signaling pathways of the host. The antioxidant potential of kaempferol in fighting HCC is promising as it inhibits only the cancerous cells without disturbing the normal cells. But, the data on its antioxidant property against HCC is scarce. Therefore the present review stresses the need for more in-depth experiments to explore new signaling pathways for cellular defense.

Funding: This research received no external funding.

\section{Acknowledgment}

The authors are thankful to Ms. Meenakshi Gupta (Research Scholar, Amity Institute of Pharmacy, Amity University, Noida, and Uttar Pradesh, India) for her insightful comments.

Conflict of Interest: The authors declare no conflict of interest.

\section{References}

1. Moratalla-López, N.; Lorenzo, C.; Alonso, G.L.; Sánchez, A.M. Kaempferol glycosides in Crocus: sources, biosynthesis, and uses. Kaempferol: Biosynthesis, Food Sources and Therapeutic Uses. Garde-Cerdán, T., Gonzalo-Diago, A., Eds. 2016, 151-95.

2. Dabeek, W.M.; Marra, M.V. Dietary quercetin and kaempferol: Bioavailability and potential cardiovascular-related bioactivity in humans. Nutrients. 2019,11, 1-19.

3. Li, H.; Ji, H.S.; Kang, J.H., Shin, D.H.; Park, H.Y.; Choi, M.S.; Lee, C.H.; Lee, I.K.; Yun, B.S.; Jeong, T.S. Soy leaf extract containing kaempferol glycosides and pheophorbides improves glucose homeostasis by enhancing pancreatic $\beta$-cell function and suppressing hepatic lipid accumulation in $\mathrm{db} / \mathrm{db}$ mice. Journal of agricultural and food chemistry. 2015, 63, 7198-210.

4. Wang, J.; Fang, X.; Ge, L.; Cao, F.; Zhao, L.; Wang, Z.; Xiao, W. Antitumor, antioxidant and anti-inflammatory activities of kaempferol and its corresponding glycosides and the enzymatic preparation of kaempferol. PLoS One. 2018, $13,1-12$.

5. Liao, W.; Chen, L.; Ma, X.; Jiao, R.; Li, X.; Wang, Y. Protective effects of kaempferol against reactive oxygen species-induced hemolysis and its antiproliferative activity on human cancer cells. European Journal of Medicinal Chemistry. 2016, 114, 24-32.

6. Ciccarone, F.; Castelli, S.; Ciriolo, M.R. Oxidative stress-driven autophagy acROSs onset and therapeutic outcome in hepatocellular carcinoma. Oxidative medicine and cellular longevity. 2019, 2019, 1-10.

7. Redza-Dutordoir, M.; Averill-Bates, D.A. Activation of apoptosis signalling pathways by reactive oxygen species. Biochimica et Biophysica Acta (BBA)-Molecular Cell Research. 2016, 1863, 2977-92.

8. Rawla, P.; Sunkara, T,; Muralidharan, P.; Raj, J.P. Update in global trends and aetiology of hepatocellular carcinoma. Contemporary oncology. 2018, 22, 141-150.

9. Suresh, D.; Srinivas, A.N.; Kumar, D.P. Etiology of Hepatocellular Carcinoma: Special Focus on Fatty Liver Disease. Frontiers in Oncology. 2020, 10, 1-9.

10. Lurje, I.; Czigany, Z.; Bednarsch, J.; Roderburg, C.; Isfort, P.; Neumann, U.P.; Lurje, G. Treatment Strategies for Hepatocellular Carcinoma-A Multidisciplinary Approach. International journal of molecular sciences. 2019, 20, 1465-89. 
11. Gentric, G.; Maillet, V.; Paradis, V.; Couton, D.; L'hermitte, A.; Panasyuk, G.; Fromenty, B.; Celton-Morizur, S.; Desdouets, C. Oxidative stress promotes pathologic polyploidization in nonalcoholic fatty liver disease. The Journal of clinical investigation. 2015, 125, 981-92.

12. El-Serag, H.B. Epidemiology of viral hepatitis and hepatocellular carcinoma. Gastroenterology. 2012, 142, $1264-73$.

13. Marra, M.; Sordelli, I.M.; Lombardi, A.; Lamberti, M.; Tarantino, L.; Giudice, A.; Stiuso, P.; Abbruzzese, A.; Sperlongano, R.; Accardo, M.; Agresti, M. Molecular targets and oxidative stress biomarkers in hepatocellular carcinoma: an overview. Journal of translational medicine. 2011, 9, 171-85.

14. Luo, J.; Xi ,J.; Gao, L.; Hu, J. Role of Hepatitis B virus capsid phosphorylation in nucleocapsid disassembly and covalently closed circular DNA formation. PLoS pathogens. 2020, 16, 1-30.

15. Perumalswami, P.V.; Klein, R.S. Hepatitis Viruses: Hepatitis C. In Viral Infections of Humans. Springer, Boston, 2014, pp. 76578.

16. Hanahan, D.; Weinberg, R.A. Hallmarks of cancer: the next generation. cell. 2011, 144, 646-74.

17. Li, Y., Li, S., Duan, X.; Yang, C.; Xu, M.; Chen, L. Macrophage Phenotypes and Hepatitis B Virus Infection. Journal of Clinical and Translational Hepatology. 2020, 8(4), 1-8.

18. Mitra, B.; Thapa, R.J.; Guo, H.; Block, T.M. Host functions used by hepatitis B virus to complete its life cycle: Implications for developing host-targeting agents to treat chronic hepatitis B. Antiviral research. 2018, 158, 185-98.

19. Ha, H.L.; Yu, D.Y. HBx-induced reactive oxygen species activates hepatocellular carcinogenesis via dysregulation of PTEN/Akt pathway. World journal of gastroenterology: WJG. 2010, 16, 4932-4937.

20. Xu, C.; Zhou, W.; Wang, Y.; Qiao, L. Hepatitis B virus-induced hepatocellular carcinoma. Cancer letters. 2014, 345, $216-22$.

21. Sung, W.K.; Zheng, H.; Li, S.; Chen, R.; Liu, X.; Li, Y.; Lee, N.P.; Lee, W.H.; Ariyaratne, P.N.; Tennakoon, C.; Mulawadi, F.H. Genome-wide survey of recurrent HBV integration in hepatocellular carcinoma. Nature genetics. 2012, 44, 765-9.

22. Pollicino, T.; Cacciola, I.; Saffioti, F.; Raimondo, G. Hepatitis B virus PreS/S gene variants: pathobiology and clinical implications. Journal of hepatology. 2014, 61, 408-17.

23. Boltjes, A.; Movita, D.; Boonstra, A.; Woltman, A.M. The role of Kupffer cells in hepatitis B and hepatitis C virus infections. Journal of hepatology. 2014, 61, 660-71.

24. Tu, Z.; Pierce, R.H.; Kurtis, J.; Kuroki, Y.; Crispe, I.N.; Orloff, M.S. Hepatitis C virus core protein subverts the antiviral activities of human Kupffer cells. Gastroenterology. 2010, 138, 305-14.

25. Shen, S.; Niso-Santano, M.; Adjemian, S.; Takehara, T.; Malik, S.A.; Minoux, H.; Souquere, S., Mariño, G.; Lachkar, S.; Senovilla, L.; Galluzzi, L. Cytoplasmic STAT3 represses autophagy by inhibiting PKR activity. Molecular cell. 2012, 48, 667-80.

26. Negro, F. Natural history of NASH and HCC. Liver International. 2020, 40, 72-6.

27. Carazo, A.; León, J.; Casado, J.; Gila, A.; Delgado, S.; Martín, A.; Sanjuan, L.; Caballero, T.; Muñoz, J.A.; Quiles, R.; Ruiz-Extremera, A. Hepatic expression of adiponectin receptors increases with non-alcoholic fatty liver disease progression in morbid obesity in correlation with glutathione peroxidase 1. Obesity surgery. 2011, 21, 492-500.

28. Romeo, S.; Kozlitina. J.; Xing, C.; Pertsemlidis, A.; Cox, D.; Pennacchio, L.A.; Boerwinkle, E.; Cohen, J.C.; Hobbs, H.H. Genetic variation in PNPLA3 confers susceptibility to nonalcoholic fatty liver disease. Nature genetics. 2008, 40, 1461-5.

29. Uchida, D.; Takaki, A.; Oyama, A.; Adachi, T.; Wada, N.; Onishi, H.; Okada, H. Oxidative Stress Management in Chronic Liver Diseases and Hepatocellular Carcinoma. Nutrients. 2020, 12, 1576-96.

30. Dongiovanni, P.; Petta, S.; Maglio, C.; Fracanzani, A.L.; Pipitone, R.; Mozzi, E.; Motta, B.M.; Kaminska, D.; Rametta, R.; Grimaudo, S.; Pelusi, S. Transmembrane 6 superfamily member 2 gene variant disentangles nonalcoholic steatohepatitis from cardiovascular disease. Hepatology. 2015, 61, 506-14.

31. Anstee, Q.M.; Reeves, H.L.; Kotsiliti, E.; Govaere, O.; Heikenwalder, M. From NASH to HCC: current concepts and future challenges. Nature reviews Gastroenterology \& hepatology. 2019, 16, 411-28.

32. Begriche, K.; Massart, J.; Robin, M.A.; Bonnet, F.; Fromenty, B. Mitochondrial adaptations and dysfunctions in nonalcoholic fatty liver disease. Hepatology. 2013, 58, 1497-507.

33. Masarone, M.; Rosato, V.; Dallio, M.; Gravina, A.G.; Aglitti, A.; Loguercio, C.; Federico, A.; Persico, M. Role of oxidative stress in pathophysiology of nonalcoholic fatty liver disease. Oxidative medicine and cellular longevity. 2018, 1-14 .

34. Panche, A.N.; Diwan, A.D.; Chandra, S.R. Flavonoids: an overview. Journal of nutritional science. 2016, 5, 1-15.

35. Kashyap, D.; Sharma, A.; Tuli, H.S.; Sak, K.; Punia, S.; Mukherjee, T.K. Kaempferol-A dietary anticancer molecule with multiple mechanisms of action: Recent trends and advancements. Journal of functional foods. 2017, 30, 203-19.

36. Imran, M.; Salehi, B.; Sharifi-Rad, J.; Aslam Gondal, T.; Saeed, F.; Imran, A.; Shahbaz, M.; Tsouh Fokou, P.V.; Umair Arshad, M.; Khan, H.; Guerreiro, S.G. Kaempferol: A key emphasis to its anticancer potential. Molecules. 2019, $24,2277$.

37. Zang, Y.; Zhang, D.; Yu, C.; Jin, C.; Igarashi, K. Antioxidant and hepatoprotective activity of kaempferol 3-O- $\beta$-D-(2, 6-di-O- $\alpha$ L-rhamnopyranosyl) galactopyronoside against carbon tetrachloride-induced liver injury in mice. Food science and biotechnology. 2017, 26, 1071-6.

38. Kim, C.; Kim, B. Anti-cancer natural products and their bioactive compounds inducing ER stress-mediated apoptosis: A review. Nutrients. 2018, 10, 1021- 1050.

39. Mello, T.; Materozzi, M.; Galli, A. PPARs and mitochondrial metabolism: from NAFLD to HCC. PPAR research. 2016, 2016, 118.

40. Xiao, Y.B.; Cai, S.H.; Liu, L.L.; Yang, X.; Yun, J.P. Decreased expression of peroxisome proliferator-activated receptor alpha indicates unfavorable outcomes in hepatocellular carcinoma. Cancer management and research. 2018, 10, 1781-1789. 
41. Chang, C.J.; Tzeng, T.F.; Liou, S.S.; Chang, Y.S.; Liu, I.M. bIntroduction. Planta med. 2011, 77, $1876-82$.

42. Raghunath, A.; Sundarraj, K.; Arfuso, F.; Sethi, G.; Perumal, E. Dysregulation of nrf2 in hepatocellular carcinoma: Role in cancer progression and chemoresistance. Cancers. 2018 10, 481.

43. Shin, S.M.; Yang, J.H.; Ki, S.H. Role of the Nrf2-ARE pathway in liver diseases. Oxidative medicine and cellular longevity. 2013, 2013, 1-10.

44. Haque, E.; Karim, M.R.; Salam Teeli, A.; Śmiech, M.; Leszczynski, P.; Winiarczyk, D.; Parvanov, E.D.; Atanasov, A.G.; Taniguchi, H. Molecular Mechanisms Underlying Hepatocellular Carcinoma Induction by Aberrant NRF2 Activation-Mediated Transcription Networks: Interaction of NRF2-KEAP1 Controls the Fate of Hepatocarcinogenesis. International Journal of Molecular Sciences. 2020, 21,5378-97.

45. Schwarz, D.S.; Blower, M.D. The endoplasmic reticulum: structure, function and response to cellular signaling. Cellular and Molecular Life Sciences. 2016, 73, 79-94.

46. Mori, K. The unfolded protein response: the dawn of a new field. Proceedings of the Japan Academy, Series B. 2015, 91, 469-80.

47. Chen, Y.; Brandizzi, F. IRE1: ER stress sensor and cell fate executor. Trends in cell biology. 2013, $23,547-55$.

48. Gong, J.; Wang, X.Z.; Wang, T.; Chen, J.J.; Xie, X.Y.; Hu, H.; Yu, F.; Liu, H.L.; Jiang, X.Y.; Fan, H.D. Molecular signal networks and regulating mechanisms of the unfolded protein response. Journal of Zhejiang University-SCIENCE B. 2017, 18, 1-4.

49. Lhomond, S.; Pallares, N.; Barroso, K.; Schmit, K.; Dejeans, N.; Fazli, H.; Taouji, S.; Patterson, J.B.; Chevet, E. Adaptation of the secretory pathway in cancer through IRE1 signaling. InStress Responses. 2015, 1292, 177-194.

50. Yu, C.Y.; Hsu, Y.W.; Liao, C.L.; Lin, Y.L. Flavivirus infection activates the XBP1 pathway of the unfolded protein response to cope with endoplasmic reticulum stress. Journal of virology. 2006, 80, 11868-80.

51. Sheng, X.; Nenseth, H.Z.; Qu, S.; Kuzu, O.F.; Frahnow, T.; Simon, L.; Greene, S.; Zeng, Q.; Fazli, L.; Rennie, P.S.; Mills, I.G. IRE1 $\alpha$-XBP1s pathway promotes prostate cancer by activating c-MYC signaling. Nature communications. 2019, 10, 1-2.

52. Preston, G.M.; Brodsky, J.L. The evolving role of ubiquitin modification in endoplasmic reticulum-associated degradation. Biochemical Journal. 2017, 474, 445-69.

53. Gorman, A.M.; Healy, S.J.; Jäger, R.; Samali, A. Stress management at the ER: regulators of ER stress-induced apoptosis. Pharmacology \& therapeutics. 2012, 134, 306-16.

54. Limonta, P.; Moretti, R.M.; Marzagalli, M.; Fontana, F.; Raimondi, M.; Montagnani Marelli, M. Role of endoplasmic reticulum stress in the anticancer activity of natural compounds. International journal of molecular sciences. 2019, 20, 961-985.

55. Walczak, A.; Gradzik, K.; Kabzinski, J.; Przybylowska-Sygut, K.; Majsterek, I. The role of the ER-induced UPR pathway and the efficacy of its inhibitors and inducers in the inhibition of tumor progression. Oxidative medicine and cellular longevity. 2019, 2019, 1-15.

56. Liu, X.; Green, R.M. Endoplasmic reticulum stress and liver diseases. Liver Research. 2019, 3, 55-64 .

57. Hirsch, I.; Weiwad, M.; Prell, E.; Ferrari, D.M. ERp29 deficiency affects sensitivity to apoptosis via impairment of the ATF6CHOP pathway of stress response. Apoptosis. 2014, 19, 801-15.

58. Xu, C.; Bailly-Maitre, B.; Reed, J.C. Endoplasmic reticulum stress: cell life and death decisions. The Journal of clinical investigation. 2005, 115, 2656-64.

59. Guo, H.; Ren, F.; Zhang, L.; Zhang, X.; Yang, R.; Xie, B.; Li, Z.; Hu, Z.; Duan, Z.; Zhang, J. Kaempferol induces apoptosis in HepG2 cells via activation of the endoplasmic reticulum stress pathway. Molecular medicine reports. 2016, 13, 2791-800.

60. Guo, H.; Lin, W.; Zhang, X.; Zhang, X.; Hu, Z.; Li, L.; Duan, Z.; Zhang, J.; Ren, F. Kaempferol induces hepatocellular carcinoma cell death via endoplasmic reticulum stress-CHOP-autophagy signaling pathway. Oncotarget. 2017, 8, 82207-82216.

61. Wang, H.; Chen, L.; Zhang, X.; Xu, L.; Xie, B.; Shi, H.; Duan, Z.; Zhang, H.; Ren, F. Kaempferol protects mice from d-GalN/LPSinduced acute liver failure by regulating the ER stress-Grp78-CHOP signaling pathway. Biomedicine \& Pharmacotherapy. 2019, 111, 468-75.

62. Mylonis, I.; Lakka, A.; Tsakalof, A.; Simos, G. The dietary flavonoid kaempferol effectively inhibits HIF-1 activity and hepatoma cancer cell viability under hypoxic conditions. Biochemical and biophysical research communications. 2010, 398, 74-8.

63. Niering, P.; Michels, G.; Wätjen, W.; Ohler, S.; Steffan, B.; Chovolou, Y.; Kampkötter, A.; Proksch, P.; Kahl, R. Protective and detrimental effects of kaempferol in rat H4IIE cells: implication of oxidative stress and apoptosis. Toxicology and applied pharmacology. 2005, 209, 114-22.

64. Wang, M.; Sun, J.; Jiang, Z.; Xie, W.; Zhang, X. Hepatoprotective effect of kaempferol against alcoholic liver injury in mice. The American journal of Chinese medicine. 2015, 43, 241-54.

65. Xu, T.; Huang, S.; Huang, Q.; Ming, Z.; Wang, M.; Li, R.; Zhao, Y. Kaempferol attenuates liver fibrosis by inhibiting activin receptor-like kinase 5. Journal of cellular and molecular medicine. 2019, 23, 6403-10.

66. Zhu, G.; Liu, X.; Li, H.; Yan, Y.; Hong, X.; Lin, Z. Kaempferol inhibits proliferation, migration, and invasion of liver cancer HepG2 cells by down-regulation of microRNA-21. International Journal of Immunopathology and Pharmacology. 2018 ,32, 1 12.

67. Yusof, H.M.; Ng, M.S.; Lam, T.W.; Kassim, M.N. Hypolipidemic effects of quercetin and kaempferol in human hepatocellular carcinoma (HepG2) cells. International Food Research Journal. 2018, 25, 241-5.

68. Shrivastava, S.; Uthra, C.; Reshi, M.; Shukla, S. Protective Role of Kaempferol Against Acrylamide Intoxication. Free Radicals \& Antioxidants. 2017, 7, 36-42. 
69. Du, Y.C.; Lai, L.; Zhang, H.; Zhong, F.R.; Cheng, H.L.; Qian, B.L.; Tan, P.; Xia, X.M.; Fu, W.G. Kaempferol from Penthorum chinense Pursh suppresses HMGB1/TLR4/NF- $\kappa B$ signaling and NLRP3 inflammasome activation in acetaminophen-induced hepatotoxicity. Food \& Function. 2020, 11, 7925-34.

70. Chen, J.; Xuan, Y.H.; Luo, M.X.; Ni, X.G.; Ling, L.Q.; Hu, S.J.; Chen, J.Q.; Xu, J.Y.; Jiang, L.Y.; Si, W.Z.; Xu, L. Kaempferol alleviates acute alcoholic liver injury in mice by regulating intestinal tight junction proteins and butyrate receptors and transporters. Toxicology. 2020, 429, 1-10.

71. Lu, Y.; Shao, M.; Xiang, H.; Zheng, P.; Wu, T.; Ji, G. Integrative transcriptomics and metabolomics explore the mechanism of kaempferol on improving nonalcoholic steatohepatitis. Food \& Function. 2020, 2020, 1-16

72. Huang, W.W.; Tsai, S.C.; Peng, S.F.; Lin, M.W.; Chiang, J.H.; Chiu, Y.J.; Fushiya, S.; Tseng, M.T.; Yang, J.S. Kaempferol induces autophagy through AMPK and AKT signaling molecules and causes G2/M arrest via downregulation of CDK1/cyclin B in SKHEP-1 human hepatic cancer cells. International journal of oncology. 2013, 42, 2069-77.

73. Fan, X.; Bai, J.; Hu, M.; Xu, Y.; Zhao, S.; Sun, Y.; Wang, B.; Hu, J.; Li, Y. Drug interaction study of flavonoids toward OATP1B1 and their 3D structure activity relationship analysis for predicting hepatoprotective effects. Toxicology. 2020, 437, 1-12.

74. Wonganan, O.; He, Y.J.; Shen, X.F.; Wongkrajang, K.; Suksamrarn, A.; Zhang, G.L.; Wang, F. 6-Hydroxy-3-O-methyl-kaempferol 6-O-glucopyranoside potentiates the anti-proliferative effect of interferon $\alpha / \beta$ by promoting activation of the JAK/STAT signaling by inhibiting SOCS3 in hepatocellular carcinoma cells. Toxicology and Applied Pharmacology. 2017, 336, 31-9.

75. Zhang, Q.; Cheng, G.; Qiu, H.; Zhu, L.; Ren, Z.; Zhao, W.; Zhang, T.; Liu, L. The p53-inducible gene 3 involved in flavonoidinduced cytotoxicity through the reactive oxygen species-mediated mitochondrial apoptotic pathway in human hepatoma cells. Food \& Function. 2015, 6, 1518-25.

76. Singab, A.N.; Youssef, D.T.; Noaman, E.; Kotb, S. Hepatoprotective effect of flavonol glycosides rich fraction from egyptianVicia calcarata desf. Against CCI 4-induced liver damage in rats. Archives of Pharmacal Research. 2005, 28, 791-8.

77. Wei, T.; Xiong, F.F.; Wang, S.D.; Wang, K.; Zhang, Y.Y.; Zhang, Q.H. Flavonoid ingredients of Ginkgo biloba leaf extract regulate lipid metabolism through Sp1-mediated carnitine palmitoyltranferase 1A up-regulation. Journal of biomedical science. 2014 21, $1-1$.

78. Cho, S.S.; Yang, J.H.; Seo, K.H.; Shin, S.M.; Park, E.Y.; Cho, S.S.; Jo, G.U.; Eo, J.H.; Park, J.S.; Oh, D.S.; Kim, J.B. Cudrania Tricuspidata Extract and Its Major Constituents Inhibit Oxidative Stress-Induced Liver Injury. Journal of medicinal food. 2019, 22, 602-13.

79. Cai, F.F.; Bian, Y.Q.; Wu, R.; Sun, Y.; Chen, X.L.; Yang, M.D.; Zhang, Q.R.; Hu, Y.; Sun, M.Y.; Su, S.B. Yinchenhao decoction suppresses rat liver fibrosis involved in an apoptosis regulation mechanism based on network pharmacology and transcriptomic analysis. Biomedicine \& Pharmacotherapy. 2019, 114, 1-10. 